\title{
A mini-review on encapsulation of essential oils
}

\begin{abstract}
Essential oils are compounds derived from the specialized metabolism of plants and have bioactive substances with strong antioxidant and antimicrobial activities in their composition. However, these compounds are affected by climate, soil, methods of oil extraction and environment. Due to this, encapsulation becomes a viable alternative for the preservation of these compounds.
\end{abstract}

Keywords: oil protection, oil extraction, bioactive substances

\author{
Volume 7 Issue I - 2018
}

\author{
Marjana Rad nz,' Elizabete Helbig,, Caroline \\ Dellinghausen Borges, ${ }^{3}$ Tatiane Kuka Valente \\ Gandra, ${ }^{3}$ Eliezer Avila Gandra ${ }^{3}$ \\ 'Department of Food Science and Technology, Federal \\ University of Pelotas, Brazil \\ ${ }^{2}$ Department of Nutrition, Federal University of Pelotas, Brazil \\ ${ }^{3}$ Center of Chemical, Pharmaceutical and Food Sciences, Federal \\ University of Pelotas, Brazil
}

Correspondence: Eliezer Avila Gandra, Center for Chemical, Pharmaceutical and Food Sciences, Federal University of Pelotas, Rio Grande do Sul, Brazil, Email gandraea@hotmail.com

Received: January 26, 2018 | Published: February 12, 2018

\section{Introduction}

Essential oils are terpene compounds derived from the specialized metabolism of aromatic plants possessing intense odor. They can be obtained from leaves, flowers and fruits and used for the production of medicines and / or foods. ${ }^{1}$ Their chemical composition can be influenced by the climate and soil of the cultivation sites of the plants as well as the extraction methods. ${ }^{2}$

These compounds have the potential to inhibit or eliminate the presence of pathogenic microorganisms and antioxidant compounds with the ability to assist in the elimination of free radicals in the body. ${ }^{3,4}$ Conversely, the efficacy of active substances of the essential oils on free radicals and pathogenic microorganisms can be influenced by environmental conditions of temperature, light and oxygen, so an alternative for the protection of these substances may be encapsulation. ${ }^{5}$ In addition, the encapsulation can act against another limitation in the application of the oils as antimicrobial agents and antioxidants, which is the characteristic strong odor that alters the sensorial characteristics of the product.

\section{Extraction of oils}

The extraction of the essential oils directly influences the profile of the compounds and can occur by different methods: cold pressing used for the extraction of oils from citrus fruits; $b$ - turbodistillation used to extract the oil from plants, whose tissues retain the sap more intensely; c-enfleurage used in extracting more unstable oils from flower petals and may lose their aromatic compounds if extracted by other methods; $d$ - by the use of a refrigerant gas, which uses a chemical substance that has an affinity with the molecules constituting the essential oil, acting as a solvent; - use of hypercritical carbon dioxide under extreme pressure (200atm) and a minimum temperature of $30^{\circ} \mathrm{C}$ for oil extraction. Nevertheless, the main form of extraction is hydrodistillation, where the raw material is completely immersed in water, with the temperature not exceeding $100^{\circ} \mathrm{C}$. $^{6}$

\section{Encapsulation}

Encapsulation is defined as a process in which the retention of a substance occurs, for example, essential oil inside another is called a capsule, which can be consumed. ${ }^{5}$ The capsules can be divided into three groups according to their size: macro, which are larger than
$5000 \mu \mathrm{m}$; micro, having a size between $0.2-5000 \mu \mathrm{m}$; and nano, which are less than $0.2 \mu \mathrm{m} .^{7}$ In relation to the core arrangement and cover, they are classified in two ways: those in which the core is clearly fixed in the center of the capsule, being circled by a determined and continuous film of the covering material; and that the nucleus is uniformly dispersed in a matrix. It can be said that the former functions as a reservoir type system, characterizing the "true microcapsules", and the latter functions as a matrix system, which characterizes the microspheres. The basic difference between the microspheres and the microcapsules is that in microspheres, a small part of the encapsulated substance is exposed on the surface, which does not occur in the microcapsules, which can have more than one nucleus or several covers for the same nucleus. ${ }^{8}$

The encapsulation technique minimizes the interactions of the substance that forms the nucleus with the environment; reduces the rate of evaporation or transfer of the core compounds into the environment; increases the ease of handling the encapsulated substance; allows for release control; reduces odors and strange flavors; and allows the encapsulated compound to disperse homogeneously in a food product. ${ }^{9}$

For the formation of the particles, the presence of a wall material is required. Various substances can be used as wall material, for example, gums (carrageenan, gum arabic, sodium alginate), carbohydrates (sugar, starch, celluloses, dextrins, corn syrup), chitosan (an alternative source obtained from shell of crustaceans ), lipids (stearic acid, wax, hydrogenated oils and fats, monoglycerides and diglycerides, paraffin, tristearin), proteins (albumin, casein, gelatin, gluten), among others. ${ }^{10}$ Among the methodologies used for the encapsulation are the atomization, extrusion, fluidized bed, coacervation, drum drying, lyophilization, ionic gelation, molecular inclusion and liposome inclusion processes. ${ }^{8}$

Coacervation is characterized by the complexation-based interaction that occurs from the mixing of solutions of substances with opposing charges, forming complexes which, by repulsion of the solvent, precipitate, forming two phases: one called "polymer rich" containing the coacervate and another called "polymer poor", in which the solvent remains in the solution. ${ }^{11}$ The simple coacervation involves a single polymer and is characterized by the separation of the liquid phase through the addition of an electrolyte (salt or alcohol) that competes for water to the colloidal solution. ${ }^{12}$ 
The process of encapsulation of compounds by ionic gelling consists of the drip of a polymer solution containing nutrients in an ionic solution, it is a simple and low cost process that allows the formation of capsules of different shapes and sizes. ${ }^{13}$ When the encapsulant, such as sodium alginate having water-soluble linear chains, comes in contact with the metal ions such as calcium chloride, a linkage occurs between the linear chains forming an insoluble gelatin. ${ }^{13,14}$ Encapsulation by emulsification involves the mixing of oily and aqueous components in the presence of an emulsifier. The adsorption of the emulsifier at the interface reduces the surface tension, which leads to the formation of an emulsion with the aid of agitation. ${ }^{15}$

\section{Discussion}

a. The process of encapsulation of essential oils stands out as a viable alternative for the preservation of the compounds against environmental conditions.

b. Also acting as a minimizer of the strong odor of the oils that is a strong limitation in the application of these as antimicrobial agents and antioxidants in foods.

\section{Acknowledgments}

None.

\section{Conflicts of interest}

The authors declare no conflicts of interest.

\section{References}

1. Silva-Santos A, Antunes AMS, Bizzo HR, et al. Análise técnica, econômica e de tendências da indústria brasileira de óleos essenciais. Rev Bras Plantas Med. 2006;8(14).

2. Oliveira RA, Reis TV, Sacramento CK, et al. Constituintes químicos voláteis de especiarias ricas em eugenol. Rev Bras Farmacogn 2009;19(3):771-775.
3. Lang G, Buchbauer G. A review on recent research results (2008-2010) on essential oils as antimicrobials and antifungals. A review. Flavour Frag J. 2012;27(1):13-39.

4. Oliveira AC, Valentim IB, Goulart MOF, et al. Fontes vegetais naturais de antioxidantes. Quimica Nova. 2009;32(3):689-702.

5. Nedovic V, Kalusevic A, Manojlovic V, et al. An Overview of encapsulation technologies for food applications. Procedia Food Science. 2011;1:1806-1815.

6. Bakkali F, Averbeck S, Idaomar M. Biological effects of essential oils A review. Food Chem Toxicol. 2008;46(2):446-475.

7. Rebello FFP. Microencapsulação de ingredientes alimentícios. Rev Agrogeoambiental. 2009. pp. 134-144.

8. Azeredo HMC. Encapsulação:Aplicação à Tecnologia de Alimentos. Braz J Food Nutr. 2005;16(1):89-97.

9. Favaro-Trindade CS, Pinho SC, Rocha GA. Revisão:Microencapsulação de ingredientes alimentícios. Braz J Food Technol. 2008;11(2):103-112.

10. Suave J, Dall'gnol EC, Pezzin APT, et al. Microencapsulação:inovação em diferentes áreas. Rev Saúde e Ambiente. 2006;7(2):12-20.

11. Strauss G, Gibson SM. Plant phenolics as cross-linkers of gelatin gels and gelatin-based coacervates for use as food ingredients. Food Hydrocolloids. 2004;18(1):81-89.

12. Vasiliu S, Popa M, Rinaudo M. Polyelectrolyte capsules made of two biocompatible natural polymers. Eur Polym J. 2005;41(5):923-932.

13. Willaert RG, Baron GV.Gel entrapmentand microencapsulation:methods, applications and engineering principles. Reviews in Chemical Engineering. 1996;12(1-2):5-205.

14. Pasqualim P, Culpi TA, Kaminski GAT, et al. Microcápsulas de alginato de cálcio e óleo vegetal pela técnica de gelificação iônica:um estudo da capacidade de encapsulamento e aplicação dermatológica. Visão Acadêmica. 2010;11(1):1518-5192.

15. Ghayempour S, Mortazavi SM. Preparation and investigation of sodium alginate nanocapsules by different microemulsification devices. $J$ Appl Polym Sci. 2015;132(17). 